\title{
Benchtop NMR Spectroscopy of Prebiotically-Relevant Peptide Reactions Enabled by Salt-Induced Chemical Shift Dispersion
}

Rio Febrian ${ }^{1}$, William J. Ona ${ }^{1}$, Juan F. Araneda ${ }^{2}$, Susanne D. Riegel ${ }^{2}$, and Paul J. Bracher ${ }^{1, *}$

1 Department of Chemistry, Saint Louis University, St. Louis, Missouri 63103 USA

2 Application Chemistry, Nanalysis Corporation, Bay 1, 46005 Street NE, Calgary, Alberta, Canada T2E 7C3

* Corresponding Author. E-mail: paul.bracher@slu.edu

Author ORCID iD Numbers:

Rio Febrian $\quad$ 0000-0002-2918-6078

Paul J. Bracher 0000-0001-5769-8364 


\section{Table of Contents}

Supplemental Experimental $\quad 3$

Materials $\quad 3$

$\mathrm{K}_{3} \mathrm{PO}_{4}$ Concentration Effect Experiments

Removal of Water from Samples at Low Pressure 3

Measurement of $\mathrm{pH} \quad 4$

Parameters for the Acquisition of NMR Spectra 4

Determination of $T_{1}$ Relaxation Times

Supplemental Discussion $\quad 5$

Interpretation of Kinetics Data for Hydrolysis of Gly 25

Scheme S1. Expected hydrolysis pathways of $\mathrm{Gly}_{3} \quad 5$

Determination of Relative Concentration of Gly $\mathrm{n}_{\mathrm{n}}$ Species in a Sample 6

Reaction Kinetics 6

Figure S1. Schematic representation of the procedure used to prepare samples for $\quad 8$ analysis by benchtop NMR spectroscopy.

Figure S2. A photograph of our Nanalysis NMReady 60e benchtop spectrometer. 9

Figure S3. High-field (400 MHz) ${ }^{1} \mathrm{H}$ NMR spectra of Gly2 with various salts. 10

Table S1. Summary of the effects of $2 \mathrm{M}$ salt additives to ${ }^{1} \mathrm{H}$ NMR spectra of $0.1 \mathrm{M} \mathrm{Gly}_{2}$. $\quad 11$

Table S2. $T_{1}$ relaxation times for $\mathrm{Gly}_{2}$ in various conditions. 12

Figure S4. Effects of $\mathrm{K}_{3} \mathrm{PO}_{4}$ on the spectral resolution of a mixture of $\mathrm{Gly}_{2}$ and $\mathrm{Gly}_{3}$. $\quad 13$

Table S3. A summary of control experiments shown in Figures S5-S10. 14

Figure S5. Benchtop ${ }^{1} \mathrm{H}$ NMR spectra in $\mathrm{D}_{2} \mathrm{O}$ of $1: 1 \mathrm{Gly}_{2}: \mathrm{Gly}_{3}$ with 15

$0 \mathrm{M} \mathrm{K}_{3} \mathrm{PO}_{4}$ and $2 \mathrm{M} \mathrm{K}_{3} \mathrm{PO}_{4}$.

Figure S6. Benchtop ${ }^{1} \mathrm{H}$ NMR spectra in $\mathrm{D}_{2} \mathrm{O}$ of 1:3 Gly ${ }_{2}: \mathrm{Gly}_{3}$ with 15

$0 \mathrm{M} \mathrm{K}_{3} \mathrm{PO}_{4}$ and $2 \mathrm{M} \mathrm{K}_{3} \mathrm{PO}_{4}$.

Figure S7. Benchtop ${ }^{1} \mathrm{H}$ NMR spectra in $\mathrm{D}_{2} \mathrm{O}$ of $3: 1 \mathrm{Gly}_{2}: \mathrm{Gly}_{3}$ with 16 $0 \mathrm{M} \mathrm{K}_{3} \mathrm{PO}_{4}$ and $2 \mathrm{M} \mathrm{K}_{3} \mathrm{PO}_{4}$.

Figure S8. Benchtop ${ }^{1} \mathrm{H}$ NMR spectra in $\mathrm{D}_{2} \mathrm{O}$ of 1:1:1 Gly:Gly 2 :Gly 3 with 16 $0 \mathrm{M} \mathrm{K}_{3} \mathrm{PO}_{4}$ and $2 \mathrm{M} \mathrm{K}_{3} \mathrm{PO}_{4}$.

Figure S9. Benchtop ${ }^{1} \mathrm{H}$ NMR spectra in $\mathrm{D}_{2} \mathrm{O}$ of 1:2:1 Gly:Gly ${ }_{2}: \mathrm{Gly}_{3}$ with 17 $0 \mathrm{M} \mathrm{K}_{3} \mathrm{PO}_{4}$ and $2 \mathrm{M} \mathrm{K}_{3} \mathrm{PO}_{4}$.

Figure S10. Benchtop ${ }^{1} \mathrm{H}$ NMR spectra in $\mathrm{D}_{2} \mathrm{O}$ of 2:1:1 Gly:Gly ${ }_{2}: \mathrm{Gly}_{3}$ with 17 $0 \mathrm{M} \mathrm{K}_{3} \mathrm{PO}_{4}$ and $2 \mathrm{M} \mathrm{K}_{3} \mathrm{PO}_{4}$.

Figure S11. Comparison of signal-to-noise ratio in ${ }^{1} \mathrm{H}$ NMR spectra of various 18 concentrations of Gly3.

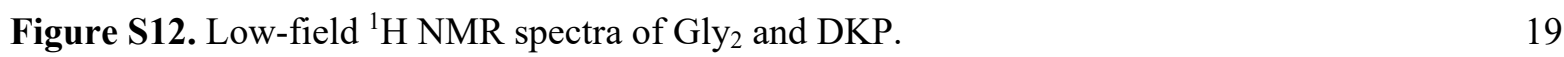

Figure S13. Low-field ${ }^{1} \mathrm{H}$ NMR spectra of $\mathrm{Gly}_{2}$ with $\mathrm{KHSO}_{4} . \quad 20$

Figure S14. Low-field ${ }^{1} \mathrm{H}$ NMR spectra of Ala and Ala.$\quad 21$

Figure S15. High-field ${ }^{1} \mathrm{H}$ NMR spectra of Ala and $\mathrm{Ala}_{2}$. 22

Supplemental References $\quad 23$ 


\section{Supplemental Experimental}

Materials. The reagents in this study were purchased from commercial sources and used without further purification. Glycine (Gly), glycylglycine (Gly2), glycine anhydride (cGly2 or 2,5-diketopiperazine, DKP), and alanine (Ala) were purchased from TCI Chemicals (Portland, OR). Alanylalanine (Ala2) was purchased from Bachem (Bubendorf, Switzerland).

Glycylglycylglycine (Gly3), $\mathrm{K}_{2} \mathrm{CO}_{3}$, and $\mathrm{K}_{2} \mathrm{SO}_{4}$ were purchased from Alfa Aesar (Haverhill, MA). $\mathrm{K}_{3} \mathrm{PO}_{4}, \mathrm{KHSO}_{4}$, and $\mathrm{K}_{2} \mathrm{HPO}_{4}$ were purchased from Sigma-Aldrich (St. Louis, $\mathrm{MO}$ ). $\mathrm{KCl}$, $\mathrm{KHCO}_{3}, \mathrm{NaOH}$, and $\mathrm{KH}_{2} \mathrm{PO}_{4}$ were purchased from Flinn Scientific (Batavia, IL). Hydrochloric acid $(\mathrm{HCl})$ was purchased from Macron Fine Chemicals (Center Valley, PA). The deuterium oxide used as solvent for NMR studies was purchased from Cambridge Isotope Labs (Cambridge, MA). Deionized water (of resistivity $18.2 \mathrm{M} \Omega \cdot \mathrm{cm}$ ) was prepared from tap water with a Millipore Milli-Q ${ }^{\circledR}$ water purification system.

$\mathrm{K}_{3} \mathrm{PO}_{4}$ Concentration Effect Experiments. In scintillation vials, solutions of $0.5 \mathrm{M}$ Gly2, $0.5 \mathrm{M} \mathrm{Gly}_{3}$, and either $0.00,0.25,0.50,1.00$, or $2.00 \mathrm{M} \mathrm{K}_{3} \mathrm{PO}_{4}$ were prepared in $\mathrm{D}_{2} \mathrm{O}$ by mixing stock solutions of $1 \mathrm{M}$ Glyn and $4 \mathrm{M} \mathrm{K}_{3} \mathrm{PO}_{4}$ in $\mathrm{D}_{2} \mathrm{O}$. NMR analysis was performed on $500 \mu \mathrm{L}$ samples by the benchtop instrument in standard $5 \mathrm{~mm}$ NMR tubes.

Removal of Water from Samples at Low Pressure. Evaporation was performed with either a Savant $^{\mathrm{TM}}$ SPD131DDA SpeedVac ${ }^{\mathrm{TM}}$ Concentrator or Labconco CentriVap ${ }^{\circledR}$ Vacuum Concentrator at room temperature under vacuum (5 Torr) overnight. Lyophilization was performed overnight on a VirTis Sentry 2.0 Lyophilizer under high vacuum (10 mT) with the condenser set to $-80{ }^{\circ} \mathrm{C}$. Each sample was covered with Parafilm (and then punctured) before being placed inside of a lyophilization canister. 
Measurement of $\mathrm{pH}$. Rapid $\mathrm{pH}$ measurements to serve as a rudimentary check that reaction aliquots were neutralized so that further hydrolysis did not occur during analysis were performed with Macherey-Nagel (Bethlehem, PA) pH-Fix 0-14 colorimetric pH strips.

Parameters for the Acquisition of NMR Spectra. A photograph of the Nanalysis NMReady 60e appears as Figure S2. All low-field spectra and high-field spectra were collected using a standard 1-D ${ }^{1} \mathrm{H}$ NMR pulse program (specifically, the default program on Nanalysis NMReady 60e and 'zg30' on Bruker's TopSpin 3.2 software). Each reaction mixture was sampled at 5 time points, and the relative ratio of the reactant to the hydrolyzed product was determined and used to construct a plot of $-\ln \left([\text { peptide }]_{t}[\text { peptide }]_{0}\right)$ vs. time. From this plot, the rate constant $(k)$ can be derived by calculating the slope of the best-fit line and dividing by the concentration of hydroxide (here, $1 \mathrm{M}$ ) according to the integrated pseudo first-order rate law shown in Equation S4.

Determination of $T_{1}$ Relaxation Times. The $T_{1}$ relaxation time was measured for each atom that produces a signal-of-interest by using an inversion-recovery pulse sequence ("tlir" on Bruker Topspin 3.2 Software), following the sample preparation outlined above. The three samples used in this work were $100 \mathrm{mM}$ Gly2 in pure $\mathrm{D}_{2} \mathrm{O}$, in $1: 1 \mathrm{D}_{2} \mathrm{O}: \mathrm{H}_{2} \mathrm{O}$, and in $\mathrm{D}_{2} \mathrm{O}$ with $2 \mathrm{M} \mathrm{K}_{3} \mathrm{PO}_{4} .90^{\circ}{ }^{1} \mathrm{H}$ pulse durations were calibrated automatically by the pulsecal command in the Topspin 3.2 Software. Sixteen experiments with different values of recovery delay $\tau=$ $[0.001,0.05,0.1,0.25,0.9,0.99,0.995,1,1.001,1.005,1.01,1.1,2,5,10$, and $15 \mathrm{~s}]$ were acquired, using 8 scans and $15 \mathrm{~s}$ of recycle delay $\left(\tau_{\text {null }}=1 \mathrm{~s}, \mathrm{~d} 1 \geq 5 \times \sqrt{ } 2 \times \tau_{\text {null }}\right)$.

1D time-domain data were transformed without any sensitivity or resolution enhancement, and the same phase and baseline corrections were applied for all resulting 1D spectra. The peak areas on the spectra were converted by Topspin's Dynamics Center to $T_{1}$ 
values by inversion recovery. Table $\mathrm{S} 2$ shows the $T_{1}$ values measured for each of the three samples. ${ }^{1}$

\section{Supplemental Discussion}

Interpretation of Kinetics Data for Hydrolysis of Gly3

This section details how the spectral data were interpreted to determine a rate constant for the hydrolysis of Glyz. Scheme S1 shows the expected hydrolysis pathways of Gly3. Under any given set of conditions, not all of these reaction pathways will be significant. Some pathways will be easier to analyze than others, while some will be very difficult to analyze by benchtop NMR spectroscopy alone.

\section{Scheme S1. Expected hydrolysis pathways of Gly3.}

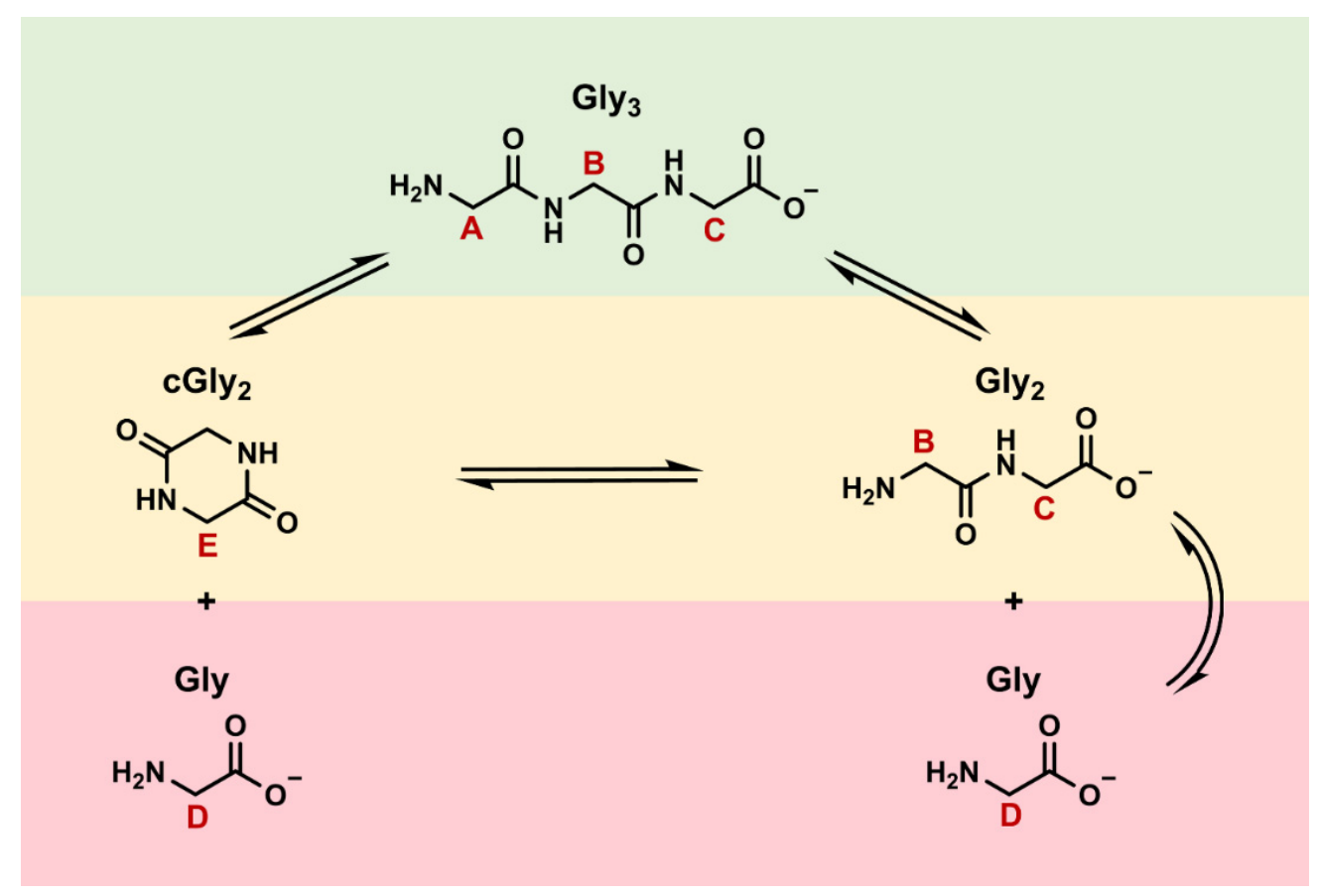


We analyzed standards of Gly, Gly2, Gly3, and cGly2 (DKP) in both $2 \mathrm{M} \mathrm{K}_{3} \mathrm{PO}_{4}$ and $\mathrm{D}_{2} \mathrm{O}$ with no salt added to determine where the peaks corresponding to these compounds appear in a ${ }^{1} \mathrm{H}$ NMR spectrum. A mixture of Gly, Gly2, and Gly3 in $\mathrm{D}_{2} \mathrm{O}$ with $2 \mathrm{M} \mathrm{K}_{3} \mathrm{PO}_{4}$ has six inequivalent methylene groups that give rise to four distinct quantifiable regions in the ${ }^{1} \mathrm{H}$ NMR spectra. Note that one methylene group on Gly2 and one on Glyz give rise to signals that are indistinguishable on the low-field instrument. The assignments of each methylene signal in these three compounds (Gly1, Gly2, Gly3) to one of the four integrated regions (A, B, C, D) are labeled in Scheme S1.

Determination of Relative Concentration of Gly $y_{n}$ Species in a Sample. For the hydrolysis of Gly3, concentrations of Gly, Gly2, and Gly3 are given by Equations below:

$$
\begin{aligned}
& {[\mathrm{Gly}]=3 \times \frac{\mathrm{D}}{(\mathrm{A}+\mathrm{B}+\mathrm{C}+\mathrm{D})} \times\left[\mathrm{Gly}_{3 \mathrm{i}}\right]} \\
& {\left[\mathrm{Gly}_{2}\right]=\frac{3}{2} \times \frac{(\mathrm{B}-\mathrm{A})+(\mathrm{C}-\mathrm{A})}{(\mathrm{A}+\mathrm{B}+\mathrm{C}+\mathrm{D})} \times\left[\mathrm{Gly}_{3 \mathrm{i}}\right]} \\
& {\left[\mathrm{Gly}_{3}\right]=3 \times \frac{\mathrm{A}}{(\mathrm{A}+\mathrm{B}+\mathrm{C}+\mathrm{D})} \times\left[\mathrm{Gly}_{3 \mathrm{i}}\right]}
\end{aligned}
$$

Equation (S3)

\section{Reaction Kinetics}

Derivation of the pseudo-first-order rate law used to determine the rate constant $(k)$. The second-order rate law for base-catalyzed hydrolysis is:

$$
\text { rate }=k[\text { peptide }]\left[\mathrm{OH}^{-}\right]
$$


The system can be approximated with a first-order rate law when the concentration of hydroxide greatly exceeds the concentration of peptide such that $\left[\mathrm{OH}^{-}\right]$effectively remains constant over the course of the reaction:

$$
\text { rate } \left.=k_{\text {obs }}[\text { peptide }] \text { when }\left[\mathrm{OH}^{-}\right]>>\text {[peptide }\right] \text {, where } k_{\mathrm{obs}}=k\left[\mathrm{OH}^{-}\right]
$$

Expressed as a differential equation for the consumption of the peptide substrate:

$$
\frac{\mathrm{d}[\text { peptide }]}{\mathrm{dt}}=-K_{\mathrm{obs}}[\text { peptide] }
$$

When this expression is integrated to Equation S4, it is apparent that the observed rate constant can be obtained as the slope of the line of $-\ln \left([\text { peptide }]_{t} /[\text { peptide }]_{0}\right)$ vs. time:

$$
\text { Integrated Rate Law: } \quad-\ln \frac{[\text { peptide }]_{\mathrm{t}}}{[\text { peptide }]_{0}}=k_{\mathrm{obs}} \mathrm{t}=k\left[\mathrm{OH}^{-}\right] \mathrm{t}
$$

Statistical Treatment of Uncertainty and Error. The error values for each rate constant, $k$, in the kinetics section of the main paper represent $95 \%$ confidence intervals based on three replicate trials (degrees of freedom $=2, \mathrm{t}^{*}$ critical value $=4.303$ ). 
Figure S1. Schematic representation of the procedure used to prepare samples for analysis by benchtop NMR spectroscopy. Aliquots of the reaction mixture taken at timed intervals were quenched by $4 \mathrm{M} \mathrm{HCl}$ solution, stripped of water at 5 Torr overnight, redissolved in $\mathrm{D}_{2} \mathrm{O}$ containing a salt (typically, $2 \mathrm{M} \mathrm{K}_{3} \mathrm{PO}_{4}$ ), and transferred to an NMR tube for analysis.
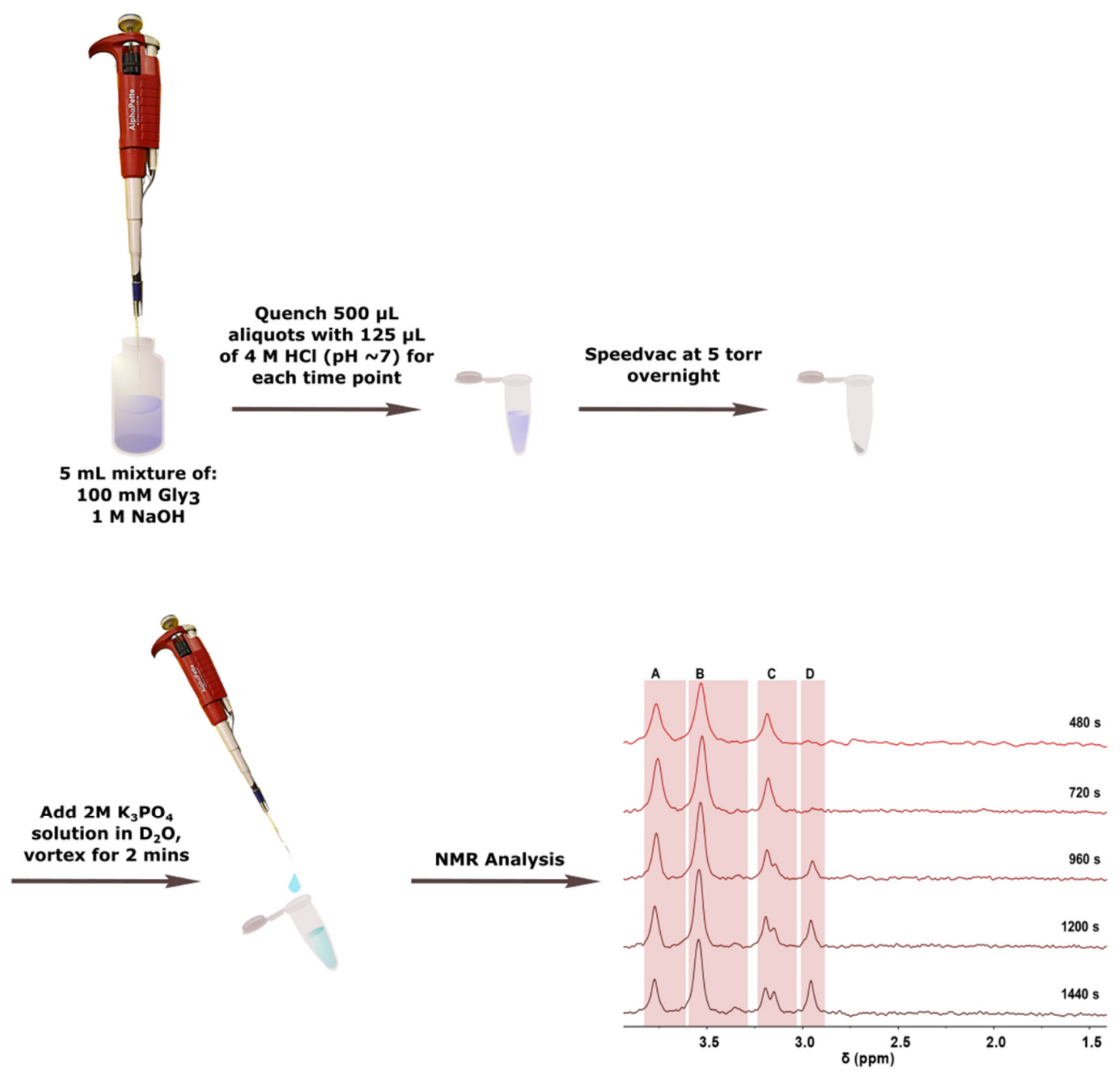
Figure S2. A photograph of our Nanalysis NMReady 60e benchtop spectrometer.

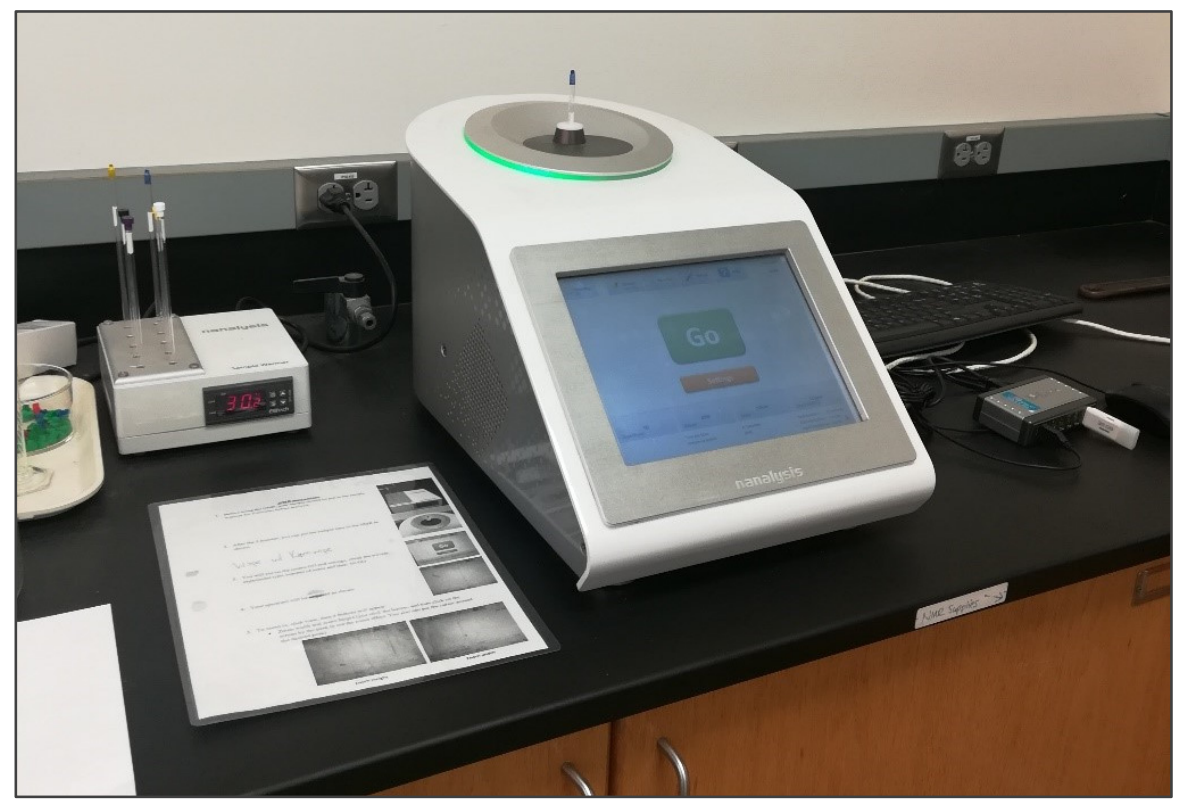


Figure S3. High-field (400 MHz) ${ }^{1} \mathrm{H}$ NMR spectra of Gly 2 with various salts. Taken from the solutions of $0.1 \mathrm{M}$ Gly $2+2 \mathrm{M}$ salt additive in $\mathrm{D}_{2} \mathrm{O}$. The standard "no salt" sample is $0.1 \mathrm{M}$ Gly2 in $\mathrm{D}_{2} \mathrm{O}$ (with no salt additive).

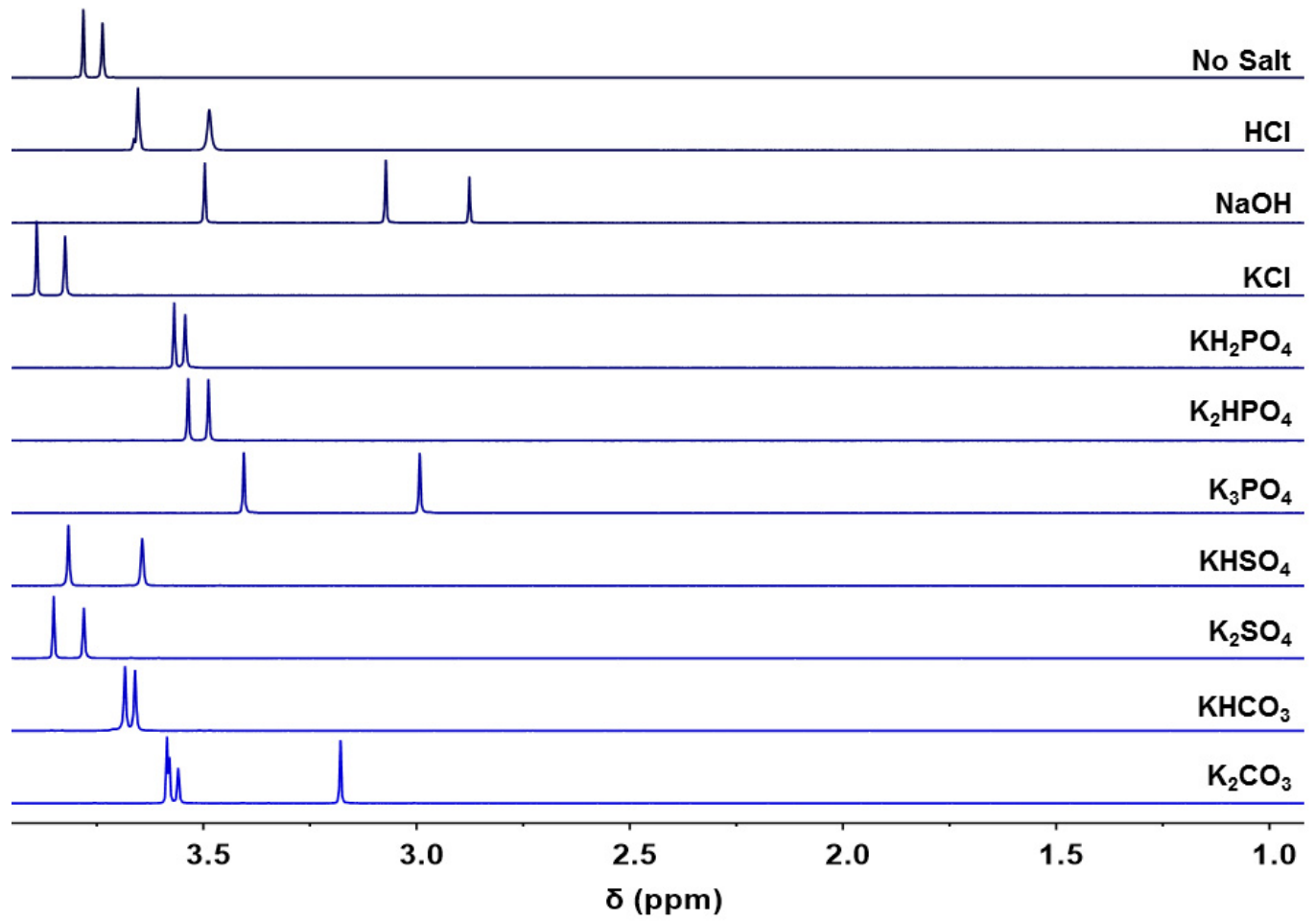


Table S1. Summary of the effects of $2 \mathrm{M}$ salt additives to ${ }^{1} \mathrm{H}$ NMR spectra of $0.1 \mathrm{M} \mathrm{Gly}_{2}$. Peaks labeled $\mathbf{A}$ correspond to the most downfield signals in the spectra, while $\mathbf{B}$ are the secondmost downfield signals (in spectra with more than one signal). Of all tested, $\mathrm{K}_{3} \mathrm{PO}_{4}$ was the only additive that (i) was fully soluble in the mixture, (ii) dispersed the chemical shifts, (iii) preserved accurate integration, and (iv) did not initiate unwanted side reactions during analysis.

\begin{tabular}{|c|c|c|c|c|c|c|}
\hline \multirow[t]{2}{*}{ Salt Additive } & \multirow[t]{2}{*}{ Solubility } & \multirow[t]{2}{*}{ pH } & \multicolumn{2}{|c|}{$\begin{array}{c}\text { Low Field (60 } \\
\text { MHz) }\end{array}$} & \multicolumn{2}{|c|}{$\begin{array}{c}\text { High Field (400 } \\
\text { MHz) }\end{array}$} \\
\hline & & & Peak A & Peak B & Peak A & Peak B \\
\hline Standard (n/a) & soluble & 7 & 1.00 & $\mathrm{n} / \mathrm{a}$ & 1.00 & 0.99 \\
\hline $\mathrm{HCl}^{\dagger}$ & soluble & 0 & 1.00 & 1.64 & 1.00 & 1.01 \\
\hline $\mathrm{NaOH}^{*}$ & soluble & 14 & 1.00 & 1.12 & 1.00 & 1.00 \\
\hline $\mathrm{KCl}$ & soluble & 7 & 1.00 & $\mathrm{n} / \mathrm{a}$ & 1.00 & 1.00 \\
\hline $\mathrm{KH}_{2} \mathrm{PO}_{4}$ & saturated & 4 & 1.00 & $\mathrm{n} / \mathrm{a}$ & 1.00 & 1.04 \\
\hline $\mathrm{K}_{2} \mathrm{HPO}_{4}$ & soluble & 9 & 1.00 & $\mathrm{n} / \mathrm{a}$ & 1.00 & 1.03 \\
\hline $\mathrm{K}_{3} \mathrm{PO}_{4}$ & soluble & 13 & 1.00 & 1.07 & 1.00 & 0.99 \\
\hline $\mathrm{KHSO}_{4}^{\dagger}$ & soluble & 1 & 1.00 & 1.41 & 1.00 & 1.00 \\
\hline $\mathrm{K}_{2} \mathrm{SO}_{4}$ & saturated & 7 & 1.00 & $\mathrm{n} / \mathrm{a}$ & 1.00 & 1.01 \\
\hline $\mathrm{KHCO}_{3}$ & saturated & 8 & 1.00 & $\mathrm{n} / \mathrm{a}$ & 1.00 & 0.89 \\
\hline $\mathrm{K}_{2} \mathrm{CO}_{3}^{\dagger}$ & soluble & 12 & 1.00 & 0.82 & 1.00 & 1.00 \\
\hline
\end{tabular}

$*$ = side reaction observed

$\dagger=$ methylene peak integrations deviated from expected 1:1 ratio at low field 
Table S2. $T_{1}$ relaxation times for $\mathrm{Gly}_{2}$ in various conditions. Measured by inversion recovery "tlir" for the signals of Gly2 in $\mathrm{D}_{2} \mathrm{O}, 1: 1 \mathrm{H}_{2} \mathrm{O}: \mathrm{D}_{2} \mathrm{O}$, and $\mathrm{D}_{2} \mathrm{O}$ with $2 \mathrm{M} \mathrm{K}_{3} \mathrm{PO}_{4}$. The addition of $\mathrm{K}_{3} \mathrm{PO}_{4}$ slightly shortened the relaxation times of the methylene signals, but not enough to require adjustment of the recycle delay (d1) setting for our NMR acquisitions.

\begin{tabular}{ccc}
\hline \multirow{2}{*}{ Condition } & \multicolumn{2}{c}{$\boldsymbol{T}_{\mathbf{1}}(\mathbf{s})$} \\
\cline { 2 - 3 } & Peak & Peak \\
& $\mathbf{A}$ & $\mathbf{B}$ \\
\hline No Salt $\left(\mathrm{D}_{2} \mathrm{O}\right)$ & 1.39 & 1.75 \\
No Salt $\left(\mathrm{D}_{2} \mathrm{O} / \mathrm{H}_{2} \mathrm{O}\right)$ & 1.39 & 1.45 \\
$2 \mathrm{M} \mathrm{K}_{3} \mathrm{PO}_{4}$ & 1.26 & 1.41 \\
\hline
\end{tabular}


Figure S4. The effects of $\mathrm{K}_{3} \mathrm{PO}_{4}$ on the spectral resolution of a mixture of $\mathrm{Gly}_{2}$ and $\mathrm{Gly}_{3}$. The signal dispersion improved with the addition of salt such that more peaks attained baseline resolution and could be integrated separately.

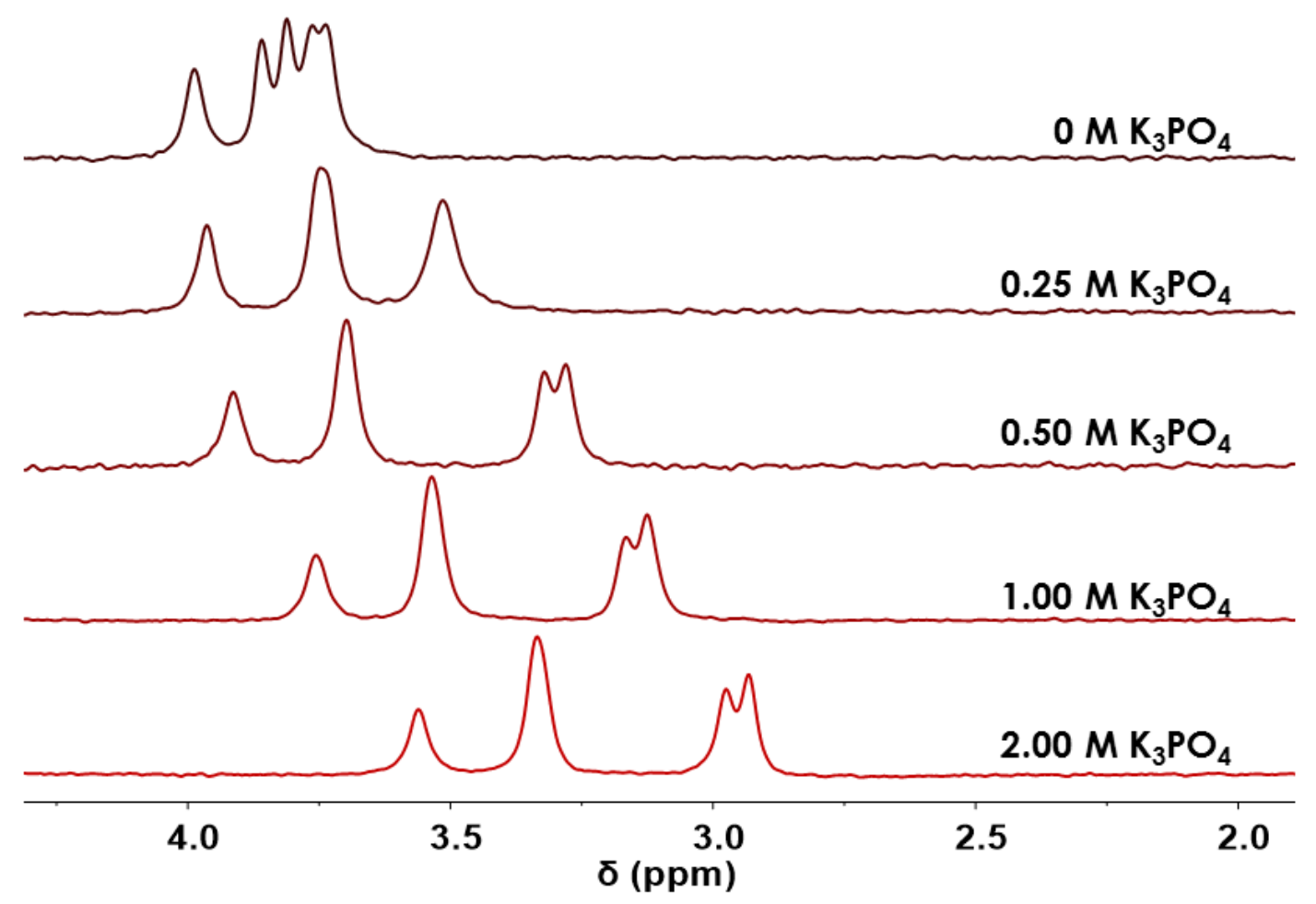


Table S3. A summary of control experiments shown in Figures S5-S10. These control experiments were designed to test whether the addition of $2 \mathrm{M} \mathrm{K}_{3} \mathrm{PO}_{4}$ to samples containing Gly ${ }_{1-3}$ interfered with the accurate integration of the peaks used to measure the relative concentrations of the compounds in each standard. The mole percentages in the mixtures were calculated from the masses of each component (labeled "Weighed") and from the NMR peak integration (labeled "Integrated"). The values measured by benchtop ${ }^{1} \mathrm{H}$ NMR matched the values expected from gravimetric analysis. Our conclusion was that the addition of $2 \mathrm{M} \mathrm{K}_{3} \mathrm{PO}_{4}$ did not interfere with the accurate integration of peaks in the NMR spectra of these peptides.

\begin{tabular}{|c|c|c|c|c|c|c|c|c|c|c|}
\hline \multirow{2}{*}{ Vial } & \multicolumn{3}{|c|}{$\begin{array}{c}\text { Mole Percent } \\
\text { in Mixture } \\
\text { (Weighed) }\end{array}$} & \multicolumn{4}{|c|}{ Peak Integration } & \multicolumn{3}{|c|}{$\begin{array}{c}\text { Mole Percent in Mixture } \\
\text { (Integrated) }\end{array}$} \\
\cline { 2 - 11 } & $\mathbf{G l y}$ & $\mathbf{G l y}_{\mathbf{2}}$ & $\mathbf{G l y}_{\mathbf{3}}$ & $\begin{array}{c}\mathbf{A} \\
\left(\mathbf{G l y}_{\mathbf{3}}\right)\end{array}$ & $\begin{array}{c}\mathbf{B} \\
\left(\mathbf{G l y}_{\mathbf{3}}+\mathbf{G l y}_{\mathbf{2}}\right)\end{array}$ & $\begin{array}{c}\mathbf{C} \\
\left(\mathbf{G l y}_{\mathbf{3}}+\mathbf{G l y}_{\mathbf{2}}\right)\end{array}$ & $\begin{array}{c}\mathbf{D} \\
(\mathbf{G l y})\end{array}$ & $\mathbf{G l y}$ & $\mathbf{G l y}_{\mathbf{2}}$ & $\mathbf{G l y}_{\mathbf{3}}$ \\
\hline $\mathbf{1}$ & 0 & 50 & 50 & 1 & 2.18 & 2.08 & 0.00 & 0.00 & 53.1 & 46.9 \\
\hline $\mathbf{2}$ & 0 & 33 & 67 & 1 & 1.53 & 1.46 & 0.00 & 0.00 & 33.1 & 66.9 \\
\hline $\mathbf{3}$ & 0 & 75 & 25 & 1 & 3.97 & 4.10 & 0.00 & 0.00 & 75.2 & 24.8 \\
\hline $\mathbf{4}$ & 25 & 25 & 50 & 1 & 1.43 & 1.54 & 0.76 & 33.81 & 21.7 & 44.5 \\
\hline $\mathbf{5}$ & 25 & 50 & 25 & 1 & 2.92 & 2.99 & 1.62 & 35.43 & 42.7 & 21.9 \\
\hline $\mathbf{6}$ & 50 & 25 & 25 & 1 & 1.81 & 2.00 & 2.48 & 56.50 & 20.7 & 22.8 \\
\hline
\end{tabular}


Figure S5. Benchtop $(60 \mathrm{MHz}){ }^{1} \mathrm{H}$ NMR spectra in $\mathrm{D}_{2} \mathrm{O}$ of 1:1 Gly2:Gly3 with $0 \mathrm{M} \mathrm{K}_{3} \mathrm{PO}_{4}$ (top) and $2 \mathrm{M} \mathrm{K}_{3} \mathrm{PO}_{4}$ (bottom).

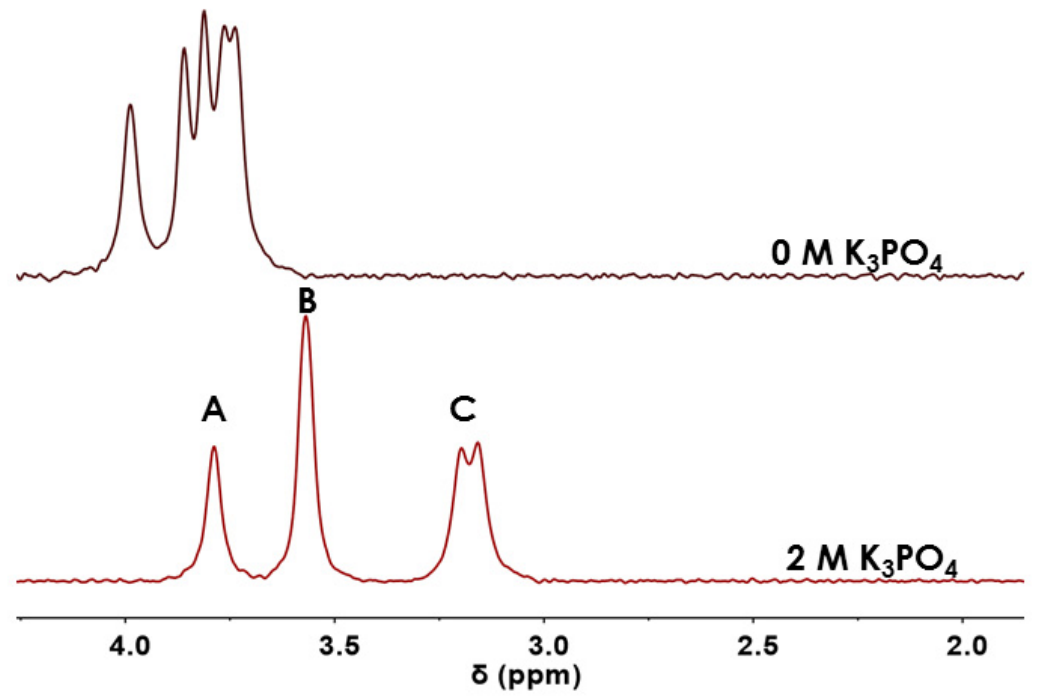

Figure S6. Benchtop $(60 \mathrm{MHz}){ }^{1} \mathrm{H}$ NMR spectra in $\mathrm{D}_{2} \mathrm{O}$ of 1:3 Gly2:Gly3 with $0 \mathrm{M} \mathrm{K}_{3} \mathrm{PO}_{4}$ (top) and $2 \mathrm{M} \mathrm{K}_{3} \mathrm{PO}_{4}$ (bottom).

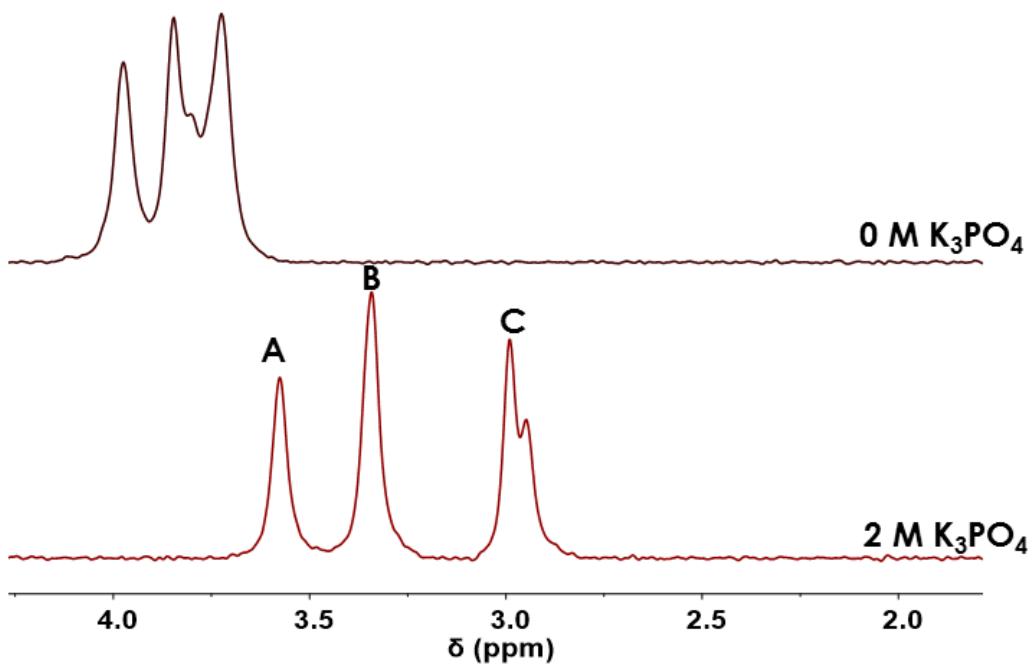


Figure S7. Benchtop $(60 \mathrm{MHz}){ }^{1} \mathrm{H}$ NMR spectra in $\mathrm{D}_{2} \mathrm{O}$ of 3:1 Gly2:Gly3 with $0 \mathrm{M} \mathrm{K}_{3} \mathrm{PO}_{4}$ (top) and $2 \mathrm{M} \mathrm{K}_{3} \mathrm{PO}_{4}$ (bottom).

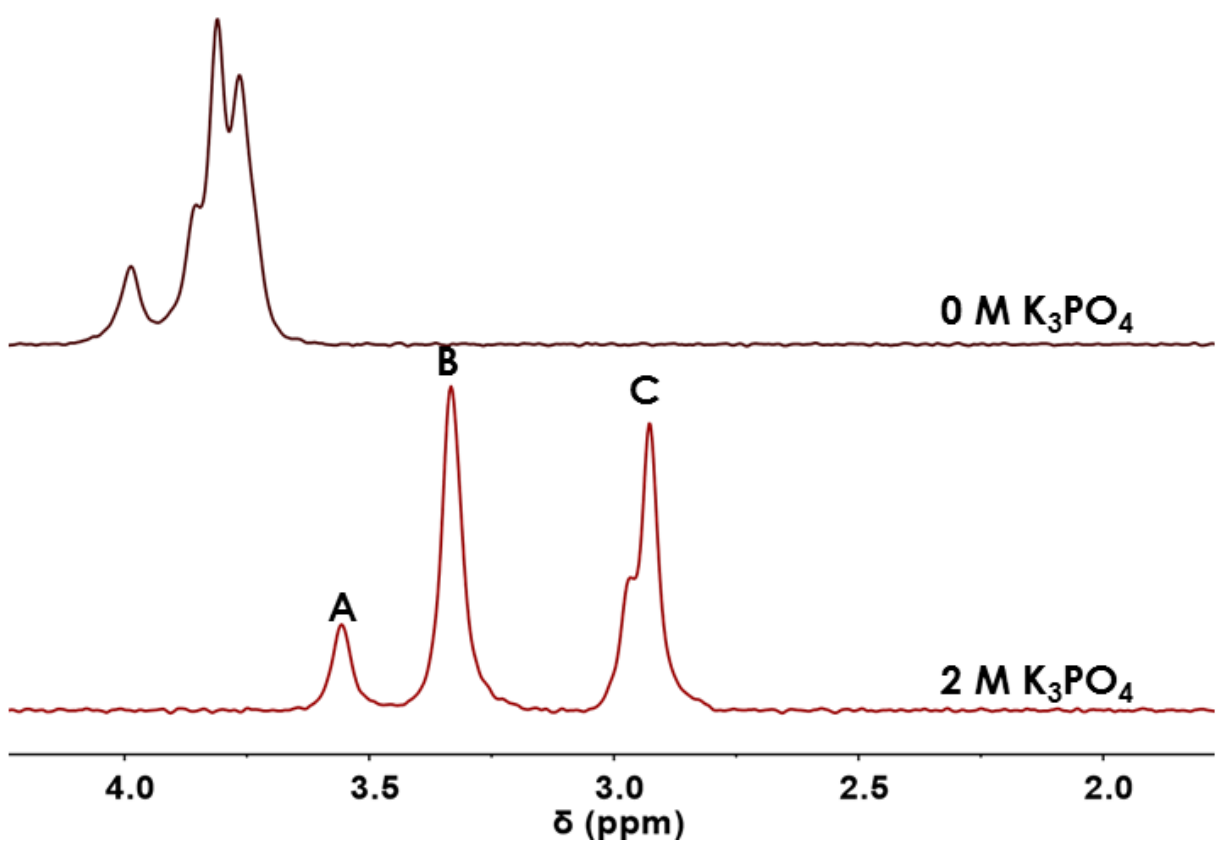

Figure S8. Benchtop $(60 \mathrm{MHz}){ }^{1} \mathrm{H}$ NMR spectra in $\mathrm{D}_{2} \mathrm{O}$ of 1:1:1 Gly:Gly2:Gly3 with $0 \mathrm{M} \mathrm{K}_{3} \mathrm{PO}_{4}$ (top) and $2 \mathrm{M} \mathrm{K}_{3} \mathrm{PO}_{4}$ (bottom).

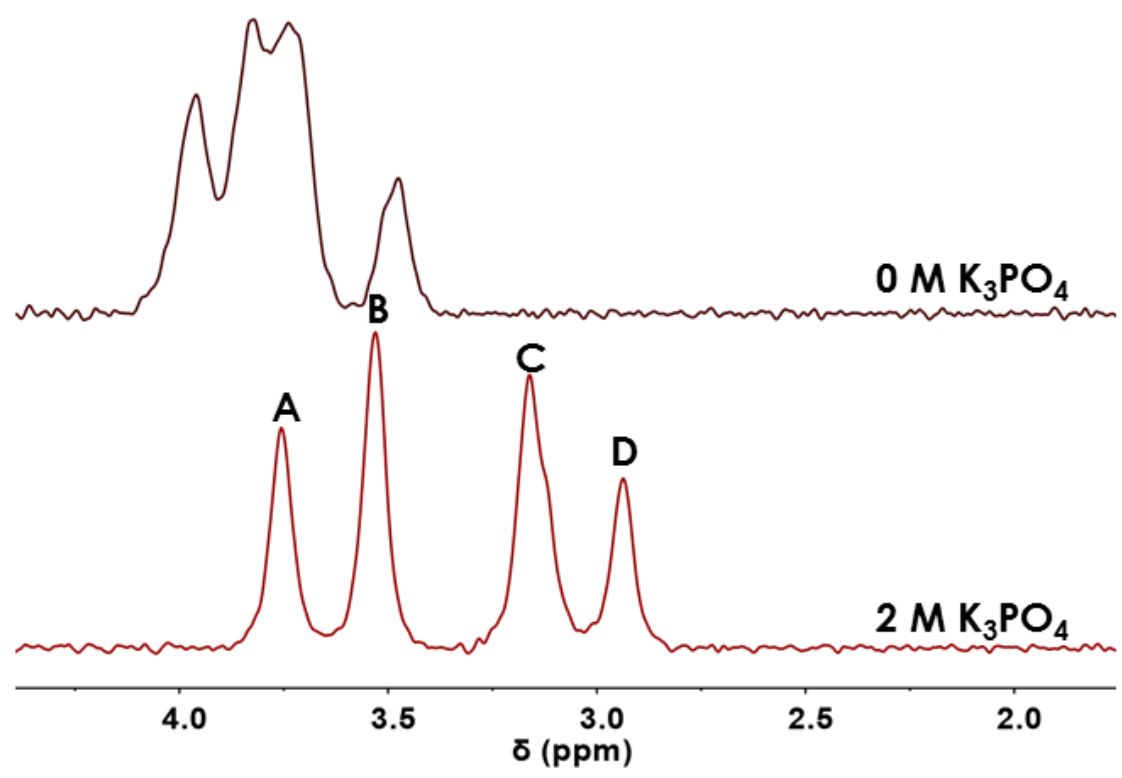


Figure S9. Benchtop (60 MHz) ${ }^{1} \mathrm{H}$ NMR spectra in $\mathrm{D}_{2} \mathrm{O}$ of 1:2:1 Gly:Gly2:Gly3 with $0 \mathrm{M} \mathrm{K}_{3} \mathrm{PO}_{4}$ (top) and $2 \mathrm{M} \mathrm{K}_{3} \mathrm{PO}_{4}$ (bottom).

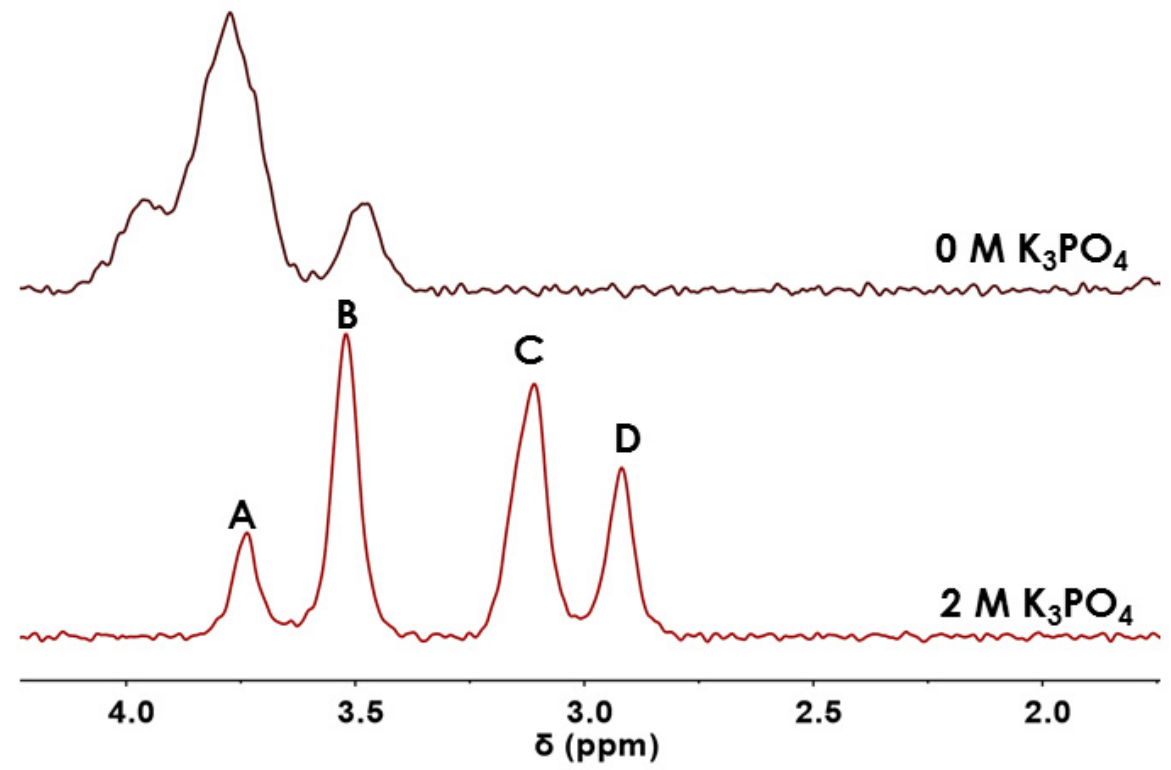

Figure S10. Benchtop (60 MHz) ${ }^{1} \mathrm{H}$ NMR spectra in $\mathrm{D}_{2} \mathrm{O}$ of 2:1:1 Gly:Gly2:Gly3 with $0 \mathrm{M} \mathrm{K}_{3} \mathrm{PO}_{4}$ (top) and $2 \mathrm{M} \mathrm{K}_{3} \mathrm{PO}_{4}$ (bottom).

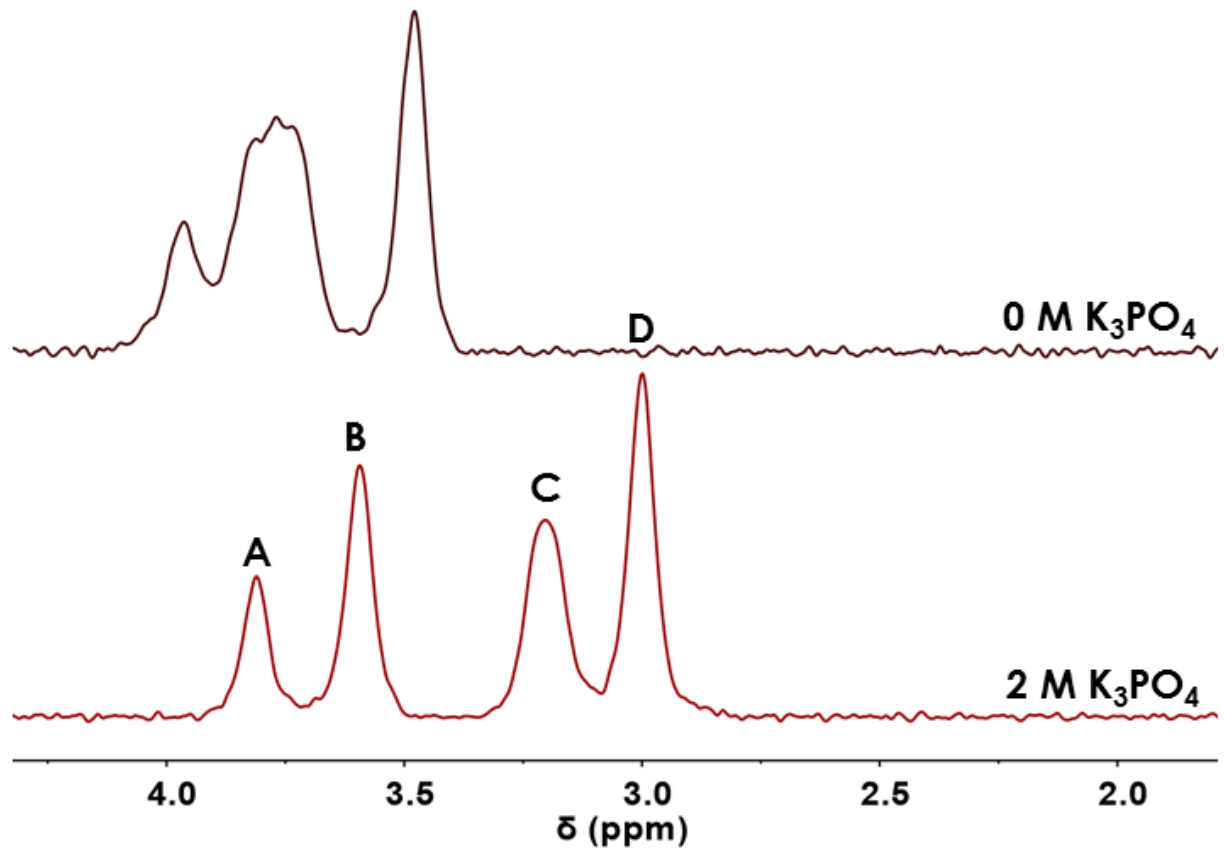


Figure S11. Comparison of signal-to-noise ratio in ${ }^{1} \mathrm{H}$ NMR spectra of various concentrations of $\mathrm{Gly}_{3}$ in $\mathrm{D}_{2} \mathrm{O}$ collected at (A) high-field, $400 \mathrm{MHz}$ and (B) low-field, $60 \mathrm{MHz}$. The peaks at $\delta 1.2$ correspond to tert-butanol, added as an internal standard.

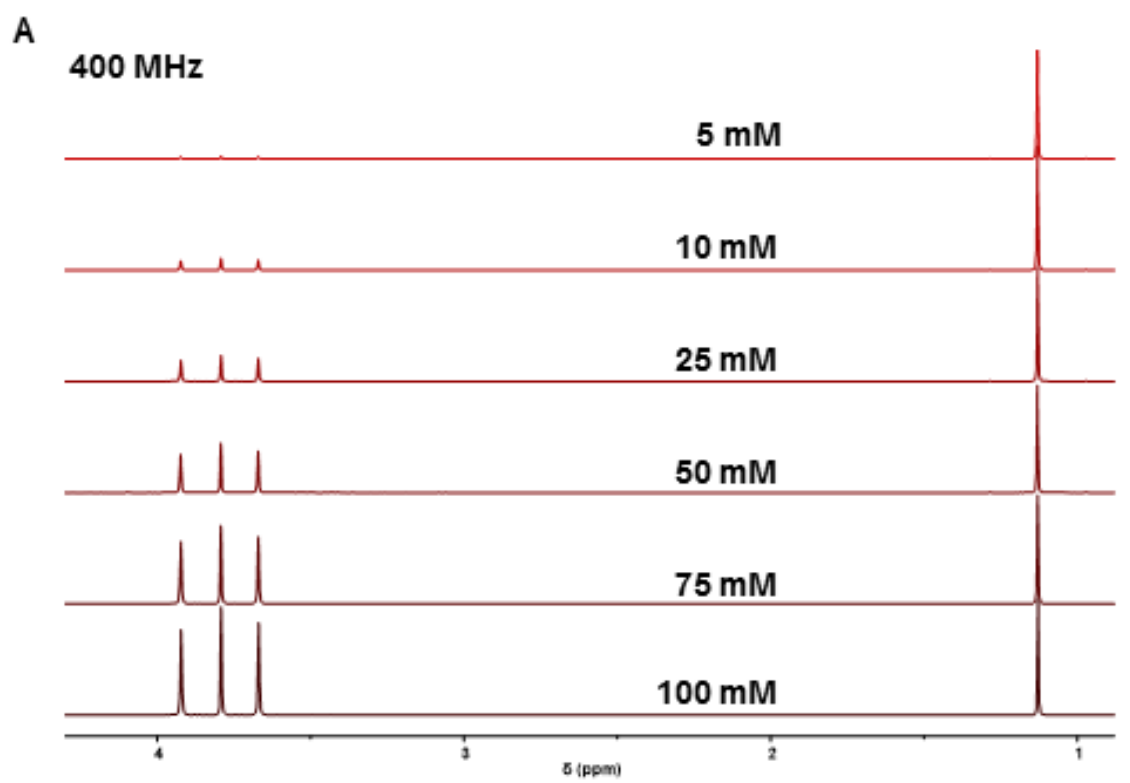

B

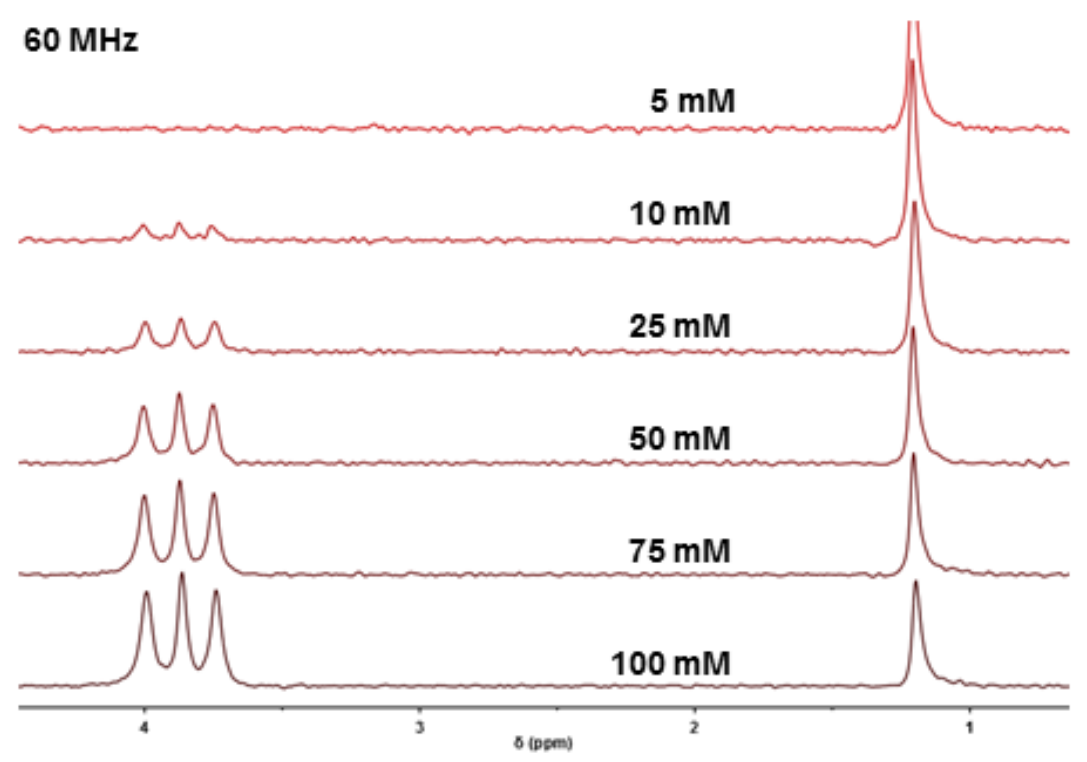


Figure S12. Low-field ${ }^{1} \mathrm{H}$ NMR spectra of Gly 2 and DKP. Benchtop $(60 \mathrm{MHz}){ }^{1} \mathrm{H}$ NMR spectra in $\mathrm{D}_{2} \mathrm{O}$ of mixtures of 2,5-diketopiperazine (cGly2 or DKP) and Gly2 with $2 \mathrm{M} \mathrm{K}_{3} \mathrm{PO}_{4}$. For these spectra, the recycle delay (d1) was set to $1 \mathrm{~s}$, so the integrations are not quantitative. These spectra were collected to determine the chemical shifts of the signals arising from these compounds to ensure they did not interfere and could be integrated individually.

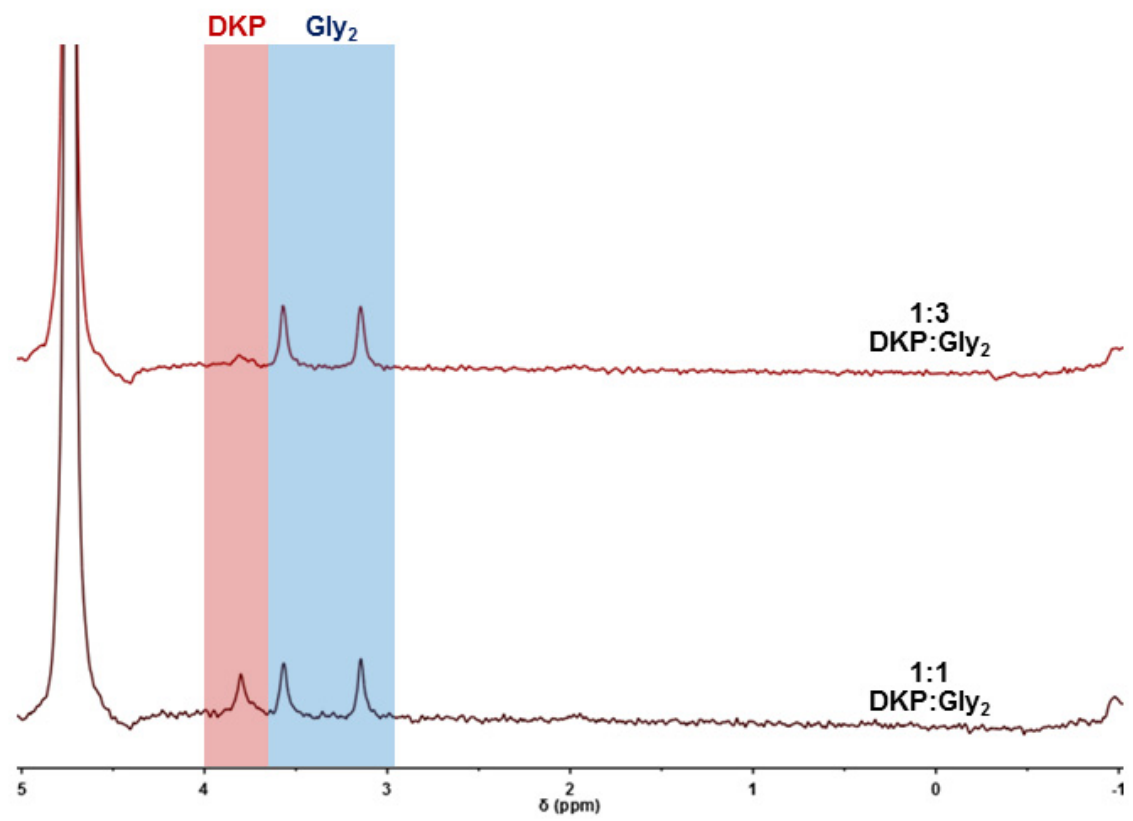


Figure S13. Low-field ${ }^{1} \mathbf{H}$ NMR spectra of Gly $\mathbf{~}_{2}$ with KHSO $_{4}$. Benchtop $(60 \mathrm{MHz}){ }^{1} \mathrm{H}$ NMR spectra in $\mathrm{D}_{2} \mathrm{O}$ of Gly2 with no additive (top), $1 \mathrm{M} \mathrm{KHSO}_{4}$ (middle), and $2 \mathrm{M} \mathrm{KHSO}_{4}$ (bottom). For these spectra, the recycle delay $(\mathrm{d} 1)$ was set to $1 \mathrm{~s}$.

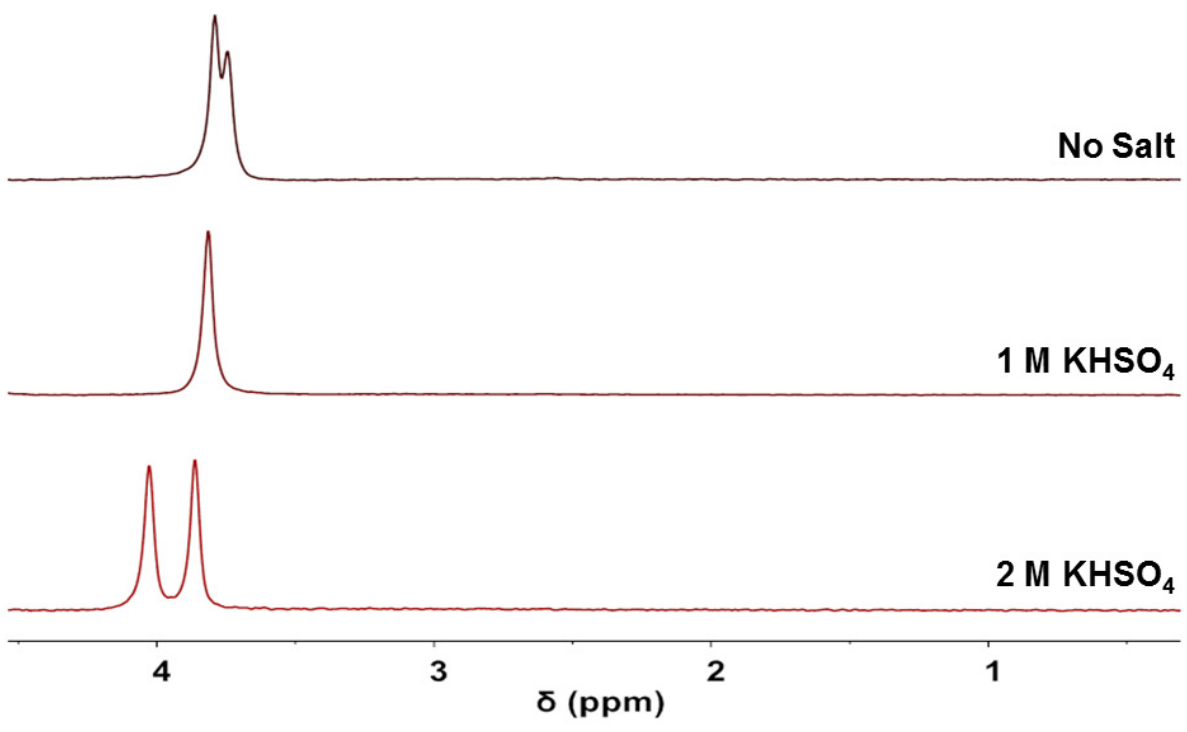


Figure S14. Low-field ${ }^{1} \mathrm{H}$ NMR spectra of Ala and Ala2. (A) $0.1 \mathrm{M}$ Ala2 before and after the addition of $1 \mathrm{M}$ and $2 \mathrm{M} \mathrm{K}_{3} \mathrm{PO}_{4}$ in $\mathrm{D}_{2} \mathrm{O}$, (B) $0.1 \mathrm{M}$ Ala 2 and $0.1 \mathrm{M}$ Ala mixture before and after the addition of $1 \mathrm{M}$ and $2 \mathrm{M} \mathrm{K}_{3} \mathrm{PO}_{4}$ in $\mathrm{D}_{2} \mathrm{O}$. For these spectra, the recycle delay (d1) was set to $15 \mathrm{~s}$.

A

$60 \mathrm{MHz}$

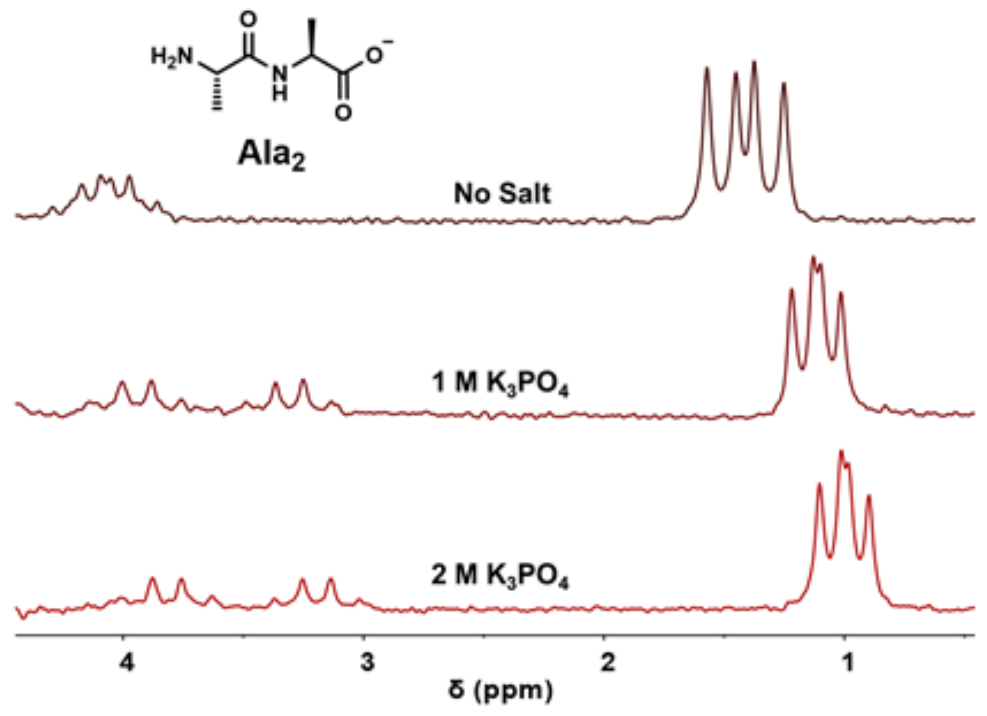

B

$60 \mathrm{MHz}$

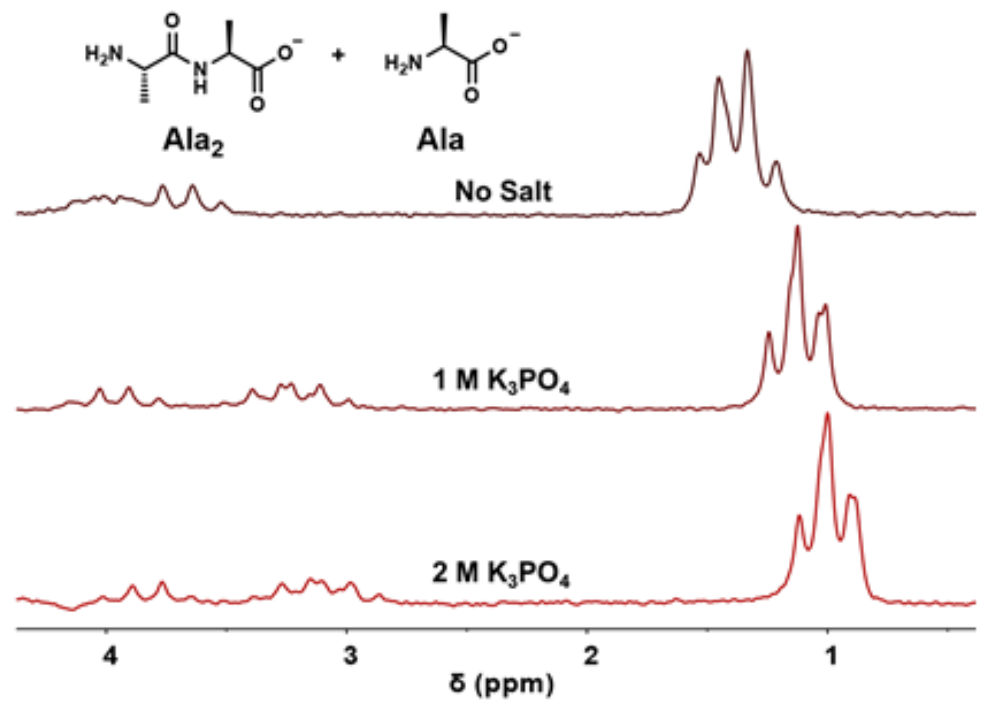


Figure S15. High-field ${ }^{1} \mathbf{H}$ NMR spectra of Ala and Ala2. (A) 0.1 M Ala 2 before and after the addition of $1 \mathrm{M}$ and $2 \mathrm{M} \mathrm{K}_{3} \mathrm{PO}_{4}$ in $\mathrm{D}_{2} \mathrm{O}$, (B) $0.1 \mathrm{M}$ Ala 2 and $0.1 \mathrm{M}$ Ala mixture before and after the addition of $1 \mathrm{M}$ and $2 \mathrm{M} \mathrm{K}_{3} \mathrm{PO}_{4}$ in $\mathrm{D}_{2} \mathrm{O}$. For these spectra, the recycle delay (d1) was set to $15 \mathrm{~s}$.

A

$400 \mathrm{MHz}$<smiles>CC(NC(=O)[C@H](C)N)C(=O)[O-]</smiles>
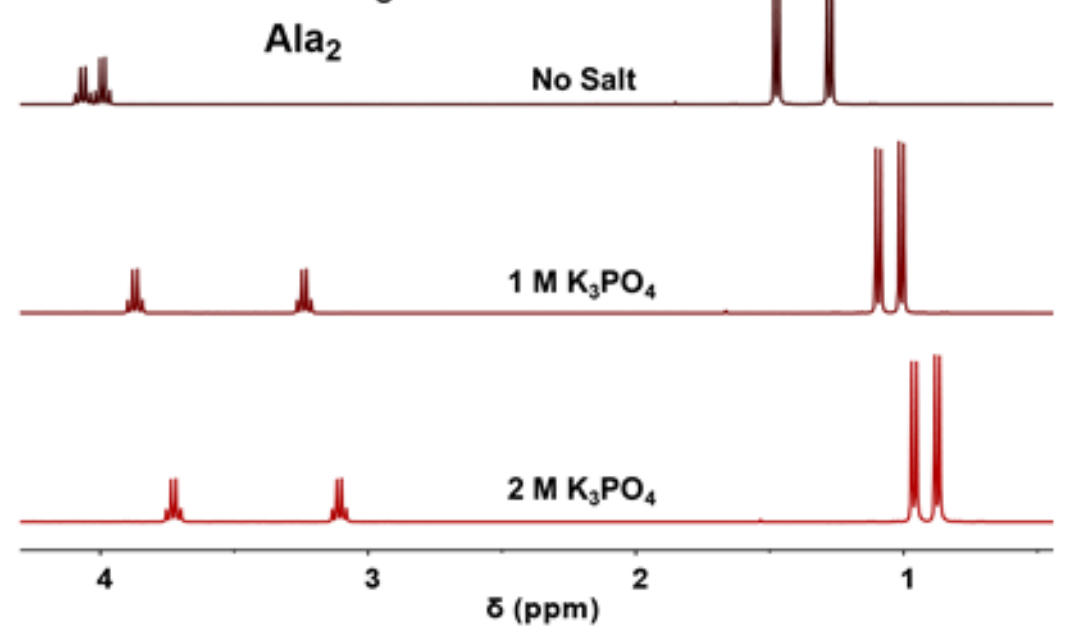

B

$400 \mathrm{MHz}$
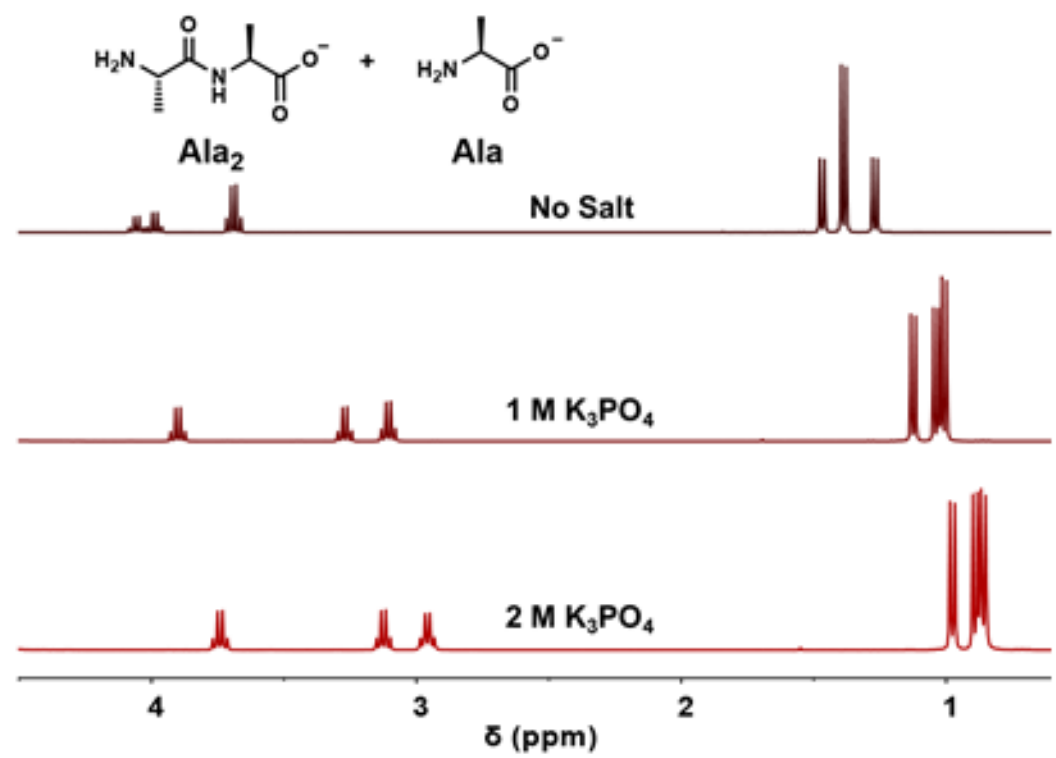


\section{Supplemental References}

1. Bruker Corporation. Dynamics Center - User Manual. 2017; pp 39-55. 